\title{
An Analytical Study on Evaluating the Performance of Developed Cultivator Mounted Seed Metering Mechanism
}

\author{
Ajay Verma ${ }^{1}$ and Ankitesh Shrivastava ${ }^{2^{*}}$ \\ ${ }^{1}$ Department of Farm Machinery and Power Engineering, IGKV Raipur (CG), India \\ ${ }^{2}$ Production Engineering, Bhilai Institute of Technology, Durg, (C.G.), India
}

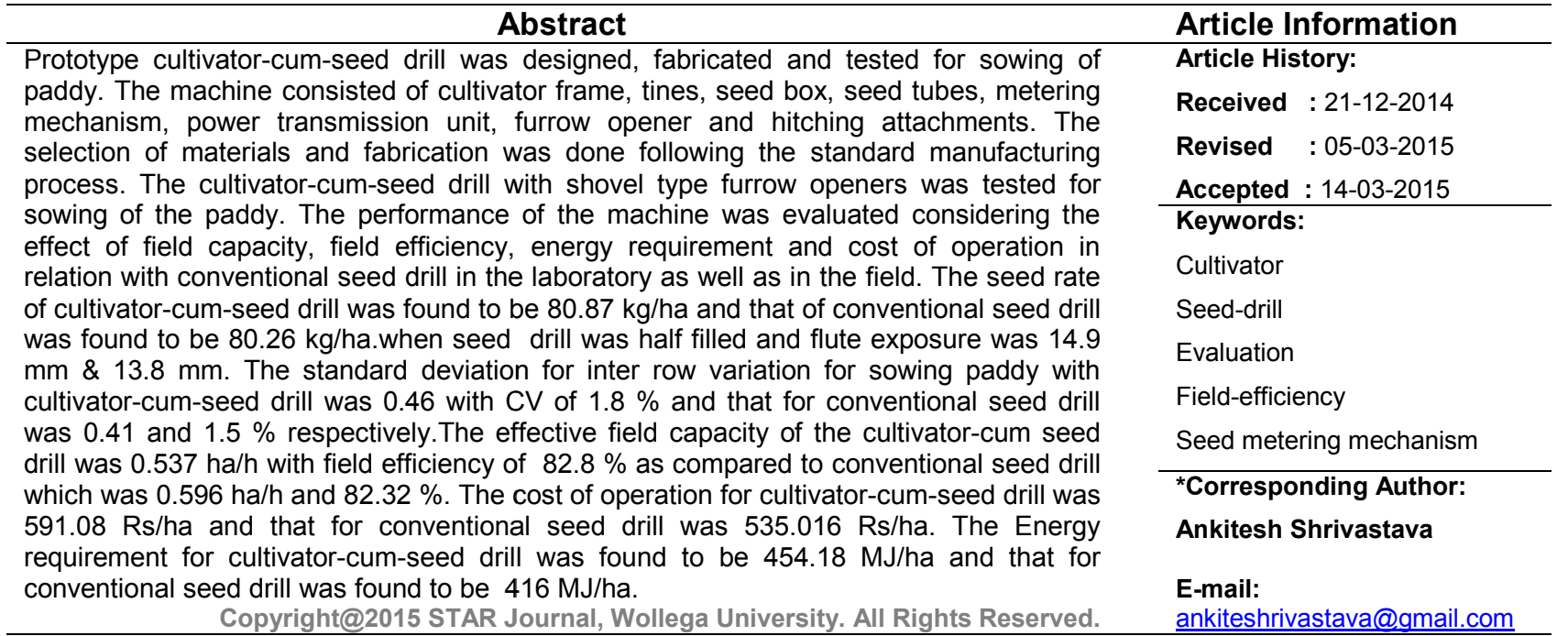

\section{INTRODUCTION}

The drill + blade harrow was evaluated with the performance of a traditional method of sowing and applying fertilizer (behind plough). The drill + blade harrow saved 46.7 man-h/ha, 53.3 bullock-h/ha, while sowing ground nut seed and applying fertilizer aver traditional methods (Kaleemullah, 1997). The no-till seed drill has resulted in a $17.09 \%$ increase in yield, $83.22 \%$ saving in energy and $80.34 \%$ saving in cost of production. There was no appreciable effect of no-tillage system on bulk density and shear strength of the soil below ploughing depth. The overall benefit was Rs 2140.33 per ha (Dixit, 2004).

Dubey (1985) found that shoe type furrow opener was found most suitable, both under dry and wet soil condition without mush disturbance of soil. To overcome the problem of clogging, the bottom of opener is closed and delivery of seed and fertilizer is from back side. It was observed that in rough, cloddy and trashy conditions 150 $\mathrm{mm}$ shoe length and above were better.

Orifice velocity was a critical factor in picking up one seed at a time, in one of the better test. The nozzles delivering speeds at rates from $11 / 2$ to 6 seeds per sec, had one seed attached $80 \%$ of the time and two seeds attached $20 \%$ of the time (Short, 1970). Cone angle of $90^{\circ}$ developed the highest retaining force. Two mathematical models were derived for the prediction of pressure distribution and forces on the ball. Model derived from stagnation point flow and boundary layer theory accurately predicted the pressure and forces on the ball for the $1.59 \mathrm{~mm}$ orifice over the range of cone ball clearance yielding high retaining forces (Shafaii, 1990).

\section{MATERIALS AND METHODS}

\section{Laboratory test}

Following test were carried out during laboratory testing.

1) Calibration of cultivator-cum-seed drill.

2) Effect of quantity of seed in hopper.

3) Mechanical damage to seed by metering mechanism.

\section{Calibration of cultivator-cum seed drill}

It was calibrated in the laboratory for metering desired quantity of seed

i. The nominal width (w) of machine was calculated as follows,

$$
\mathrm{W}=\mathrm{M} \times \mathrm{S}
$$

Where, $M=$ Number of furrow openers; $S=$ The spacing between the openers $(\mathrm{m})$ and $\mathrm{W}=$ Width $(\mathrm{m})$ 
ii. The circumference of the ground driving wheel was measured,

$$
C=\pi \times D
$$

Where, $D=$ Diameter of ground wheel $(m)$ and $C=$ Circumference of driving wheel $(\mathrm{m})$.

iii. Area covered in one revolution of wheel was calculated, $A=\pi \times D \times W$

iv. The calibration was done for 20 revolution of the ground wheel. Therefore the area covered in 20 revolutions of wheel was calculated from the area covered in one revolution multiplied by 20 (No. of revolution).

v. Ground wheel drive was made free to rotate by jacking up the drill. One mark was puton the drive wheel and another mark on the body of the drill so that the revolution was counted correctly

vi. Hopper was filled with the seed in respective chamber of the hopper. Polythene bags were tied at the open end of the seed delivery tube.

vii. The rate control adjustment for the seed was set for maximum drilling.

viii. The drive wheel was rotated for 20 revolutions and the seed collected in the bags were weighed. ix. The seed rate was calculated by the following formula, Seed rate $(\mathrm{kg} / \mathrm{ha})=$ weight of seed collected $/$ area covered.

Above procedure was repeated by adjusting suitably the rate control till required seed rate ofseed was obtained.

\section{Effect of Quantity of Seed in Hopper}

Seed box was completely filled by seed and the seed rate was checked. The process was repeated by filling the hopper for full, $3 / 4,1 / 2$, and $1 / 4$ capacity and the corresponding seed rates were measured

\section{Mechanical Damage to the Seed by Metering Mechanism}

During calibration, seeds were collected from below the furrow openers and visually broken seeds were counted. The broken seeds were weighed and percentages of damaged seeds were determined.

$$
\text { Broken Seeds }(\%)=\frac{\text { Weight of broken seeds }}{\text { Weight of total seeds collected }} * 100
$$

\section{Field Test}

The field performance was conducted in order to obtain actual data for overall machine performance, operating accuracy, work capacity, and field efficiency. The conventional seed-drill in operation is shown in Figure1.

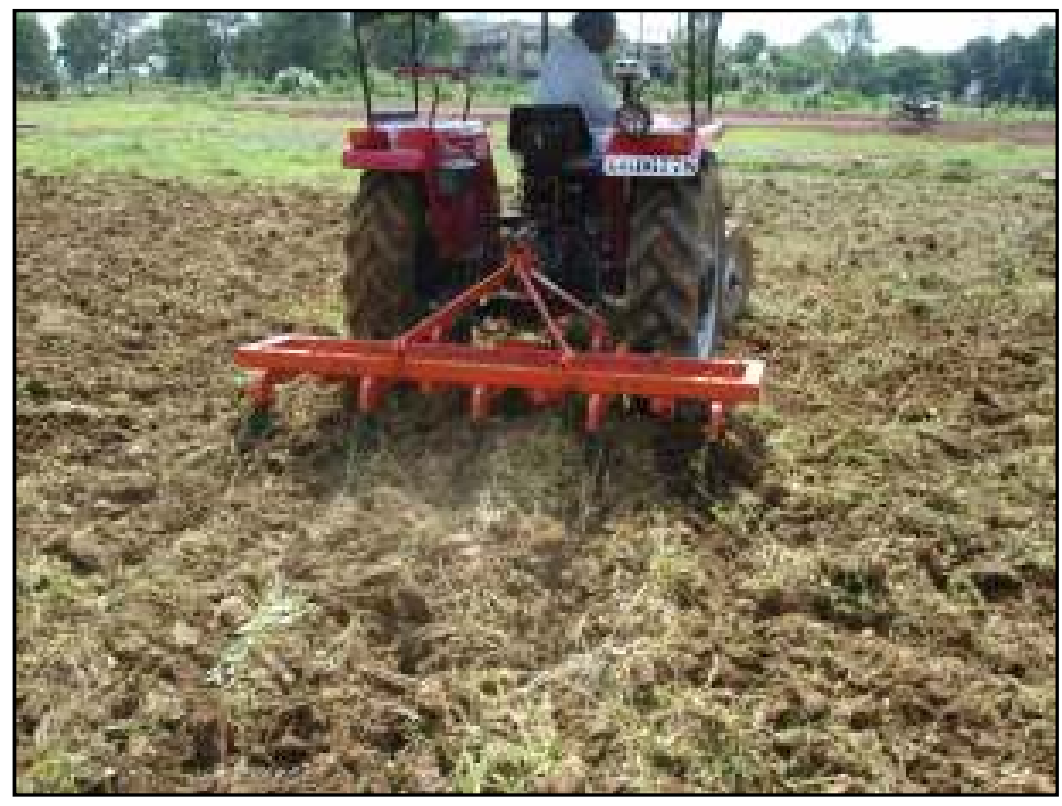

Figure 1: Conventional seed-drill

The prototype cultivator-cum-seed drill was field tested for its mechanical performance in 0.21 ha at Faculty of Agricultural Engineering, IGKVV, Raipur. Following observations were recorded during the field tests.

1. Moisture content of the soil

2. Bulk density of the soil

3. Time lost in turning at head land, adjustment and refilling the hopper.

4. Depth of placement of the seed.

5. Effective width of coverage.

6. Total time of sowing operation

7. Uniformity of seed placement.

\section{Moisture Content}

Moisture content (\%) on dry basis of soil was measured by oven drying method. The soil samples from different locations within a plot were taken using core sampler $37 \mathrm{~mm}$ in diameter and $125 \mathrm{~mm}$ in length and a soil auger. The collected soil sample from each location were weighed initially and then kept in an oven for 24 hours at $105{ }^{0} \mathrm{C}$ for obtaining dry weight of soil and moisture content was calculated as follows:

$$
\frac{w_{1}-w_{2}}{w_{2}} * 100
$$

Where, $\mathrm{MCd}=$ Moisture content of soil on dry weight basis; $\mathrm{W} 1=$ Weight of wet soil and W2= Weight of dry soil 


\section{Bulk Density}

Bulk density of the soil is the oven dry mass per unit volume of the soil. It was measured by using core sampler having $37 \mathrm{~mm}$ diameter and $60 \mathrm{~mm}$ length by taking different soil samples from different locations of the field. The bulk density was calculated by using formula:

Where,

$$
\delta=\frac{\mathrm{M}}{\mathrm{V}}
$$

$\delta=$ bulk density of soil, $\mathrm{g} / \mathrm{cm}^{3}$

$\mathrm{M}=$ oven dry mass of soil, $\mathrm{g}$

$\mathrm{V}=$ Volume of core sampler, $\mathrm{cm}^{3}$

\section{Speed of Operation}

To calculate the speed of operation two poles $20 \mathrm{~m}$ apart were placed approximately in the middle of test run. The speed was calculated from the time required for the machine to travel the distance of $20 \mathrm{~m}$.

\section{Measurement of Time Lost in Turning}

In the plot of $70330 \mathrm{~m}$ the cultivator-cum-seed drill was operated length wise from one end to other. Time required to travel and turning at headland was measured. The time loss in $\mathrm{h} / \mathrm{ha}$ was also calculated.

\section{Depth and Width of Operation}

The depth of sowing was measured at different locations with the help of scale and average was taken, for measurement of actual width of operation of the machine the width covered in three passes of the machine was measured with tape and actual width of operation was calculated.

\section{Measurement of Wheel Slip}

To calculate the wheel slip the tractor was operated at implement with load and without load condition. A mark on tractor drive wheel with colored tapes and the distance the tractor moves forward is measured , 10 revolutions under no load (A) and on the same surface and with the same number of revolutions with load $(B)$, wheel slip was calculated as follows:

$$
\text { Wheel Slip }(\%)=\frac{\mathrm{A}-\mathrm{B}}{\mathrm{A}} * 100
$$

Where, $A=$ No. of revolutions of drive wheel for a given distance under no load and $B=$ No. of revolutions of drive wheel for the same distance at load.

\section{Seed Emergence}

Number of plants emerged were counted in one meter of row in one run at the stage when almost all the plants were growing up to three leaves. Different sampling areas should be randomly selected in a test plot.

\section{Plant Population Achieved}

An area of 1 sq. $m$ was selected and the numbers of plants in that area were counted for each crop. The plants were counted in different places for $1 \mathrm{sq}$. $\mathrm{m}$ and the average value was taken.

\section{Field Capacity and Field Efficiency of the Machine}

Theoretical field capacity and effective field capacity were determined on the basis of area covered per unit time.

\section{Theoretical field capacity}

On the basis of width of furrow and speed, theoretical field capacity was calculated by following formula,

$$
\text { Theoretical field capacity }\left(\frac{\mathrm{ha}}{\mathrm{h}}\right)=\frac{\mathrm{W} * \mathrm{~S}}{10}
$$

Where, $\mathrm{S}=$ Speed of operation, $\mathrm{km} / \mathrm{h} ; \mathrm{W}=$ Theoretical width covered and $\mathrm{m}=$ Number of furrow openers multiplied by distance between the furrow opener, $\mathrm{m}$.

\section{Effective Field Capacity}

The seed drill was continuously operated in the field for 0.21 ha to assess its actual coverage. The time required for complete sowing was recorded and Effective field capacity was calculated.

$$
\text { Effective field capacity }=\frac{\mathrm{A}}{\mathrm{T}}
$$

Where, $\mathrm{A}=$ Actual area covered, (in ha.) and $\mathrm{T}=$ Total time required to cover the area, (in hrs.)

\section{Field Efficiency}

$$
\text { Field efficiency }(\eta)=\frac{\text { Effective field capacity }}{\text { Theoretical field capacity }} * 100
$$

\section{Cost of Operation}

The cost of operation of machine was calculated on the basis of the time and the number of operations required for sowing of the seed.

\section{Energy Requirement}

The operational energy requirement for cultivator-cum-seed drill was calculated on the basis of fuel, labour and time required for the sowing and other related operations.

\section{RESULTS AND DISCUSSIONS}

Specifications of the tractor drawn cultivator-cum-seed drill (Figure 2) are as follows,
Length, $\mathrm{mm}$
$2160 \mathrm{~mm}$
Width, $\mathrm{mm}$
$2100 \mathrm{~mm}$
Height, mm
$1750 \mathrm{~mm}$
Row spacing, mm
$230 \mathrm{~mm}$
Furrow opener
Shovel type

\section{Moisture Content and Bulk Density of Soil}

Moisture content on dry basis of soil was measured by oven dry method five soil samples were taken randomly at $5.6,5.8,6.2,6.6$ and $6.8 \mathrm{~cm}$ depth from surface of soil using core sampler of $5.6 \mathrm{~cm}$ diameter and $8.6 \mathrm{~cm}$ height.

Moisture content at 5.6, 5.8, 6.2, 6.6 and $6.8 \mathrm{~cm}$ depth was found to be $16.44,16.49,16.44,15.70$, and 16.57 on dry basis respectively. Bulk density of soil was measured by core sampler. Bulk density of soil (before operation) was found to be $1.18,1.03,1.151 .19$, and $1.19 \mathrm{~g} / \mathrm{cm}^{3}$ at the respective depth. And after operation was found to be $0.868,0.856,0.829,0.918,0.938 \mathrm{~g} / \mathrm{cm}^{3}$ at respective depth (Table 1).

\section{Speed of Operation}

The speed of operation was calculated from the time required by the machine to travel the distance of $20 \mathrm{~m}$. the average speed of operation was found to be $4.5 \mathrm{~km} / \mathrm{h}$ (Table 2).

\section{Time Lost in Turning}

The average time loss during turning at head land was $11.76 \mathrm{~S}$. the average time loss in $\mathrm{h} / \mathrm{ha}$ found to be 0.22 (Table 3). 


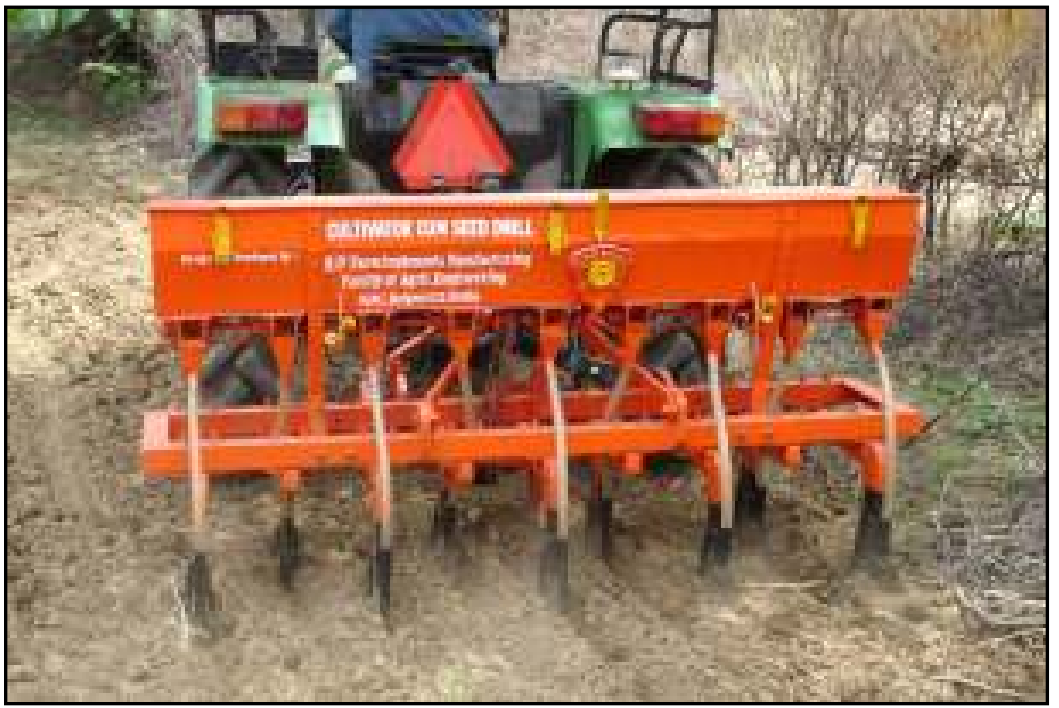

Figure 2: Field performance test for prototype cultivator

Table 1: Moisture content and bulk density

\begin{tabular}{ccccc}
\hline No & Depth , cm & Moisture content \% (db) & $\begin{array}{c}\text { Bulk density } \mathbf{~} / \mathbf{c m}^{3} \\
\text { (Before operation) }\end{array}$ & $\begin{array}{c}\text { Bulk density } \mathbf{~} / \mathbf{c m}^{\mathbf{3}} \\
\text { (After operation) }\end{array}$ \\
\hline 1 & 5.6 & 16.44 & 1.18 & 0.868 \\
2 & 5.8 & 16.49 & 1.03 & 0.856 \\
3 & 6.2 & 16.44 & 1.15 & 0.829 \\
4 & 6.6 & 15.70 & 1.19 & 0.918 \\
5 & 6.8 & 16.57 & 1.19 & 0.938 \\
\hline
\end{tabular}

Table 2: Data pertaining to the field test of cultivator

\begin{tabular}{cccc}
\hline S N & Distance (in $\mathbf{~ m})$ & Time (in sec) & Speed (in $\mathbf{~ m e c ) ~}$ \\
\hline 1 & 20 & 15.19 & 1.316 \\
2 & 20 & 15.16 & 1.319 \\
3 & 20 & 15.25 & 1.311 \\
4 & 20 & 17.00 & 1.176 \\
5 & 20 & 16.50 & 1.212 \\
\hline Average & $\mathbf{2 0}$ & $\mathbf{1 5 . 8 2}$ & $\mathbf{1 . 2 6 6}$ \\
\hline
\end{tabular}

Table 3: Time lost in turning at head land

\begin{tabular}{cccc}
\hline No & Time lost in one turn (s) & Area covered in one turn $\left(\mathbf{m}^{2}\right)$ & Average time loss $(\mathbf{h} / \mathbf{h a})$ \\
\hline 1 & 11.5 & & \\
2 & 11.7 & $2.10370=147$ & 0.22 \\
3 & 11.6 & & \\
4 & 12.0 & & \\
5 & 12.0 & & \\
\hline
\end{tabular}

\section{Wheel Slippage}

The average wheel slippage for cultivator was found to be 14.4 (Table 4).

\section{Depth of Operation}

The average depth of operation was found to be 129.2 $\mathrm{mm}$ (Table 5).

\section{Soil Inversion}

The soil inversion was observed to judge the quality of work with the developed tillage implement. It was observed by counting number of inverted weeds before and after operation.

Table 6 shows that soil inversion increased from 75.83 to $77.20 \%$ with increase in depth from 8.2 to $12.5 \mathrm{~cm}$ respectively. The average weed efficiency was found to be $76.42 \%$. The data showed that the effective field capacity of the cultivator was 0.826 ha/h with field efficiency $87.40 \%$. The average depth of operation was
$129.2 \mathrm{~mm}$.The cost of operation was $434.43 \mathrm{Rs} / \mathrm{ha}$ and energy requirement was $51.04 \mathrm{MJ} / \mathrm{ha}$.

\section{Laboratory Test}

\section{Calibration}

The Tractor drawn prototype cultivator-cum-seed drill was calibrated in the laboratory for desired seed rate by adjusting the exposed length of the flutes.

For paddy seeds, the highest seed rate $124.14 \mathrm{~kg} / \mathrm{ha}$ was found with $18.6 \mathrm{~mm}$ exposed flute length and one fourth filled. Whereas minimum seed rate $49.07 \mathrm{~kg} / \mathrm{ha}$ was with $11.2 \mathrm{~mm}$ exposure of flute and hopper completely filled. The seed rate close to recommended seed rate was found $80.87 \mathrm{~kg} / \mathrm{ha}$ when seed drill was three fourth filled and flute exposure was $10 \mathrm{~mm}$. It is also revealed that, for all the capacities of hopper one fourth, half, three fourth and full with $14.9 \mathrm{~mm}$ flute exposure the seed rate was close to the recommended seed rate. The observed seed rates for $14.9 \mathrm{~mm}$ flute exposure were $77.45 \mathrm{~kg} / \mathrm{ha}, 78.44$ 
Ajay Verma and Ankitesh Shrivastava

$\mathrm{kg} / \mathrm{ha}, 80.87 \mathrm{~kg} / \mathrm{ha}$, and $86.87 \mathrm{~kg} / \mathrm{ha}$ for full, three fourth, half, and one fourth hopper capacity (Table 8)

Mechanical Damage to Seed by Metering Mechanism

Visual observations for mechanical damage due to metering mechanism were recorded broken seeds were separated and weighed. The results are shown in table 9.
Sci. Technol. Arts Res. J., Jan-March 2015, 4(1): 165-170

Seed collected in 10 revolutions

Area covered in 10 revolutions, sq. $\mathrm{m}=29.18$

The average mechanical damage of seeds due to metering was $1.8 \%$ for rice. This value was within the permissible limit.

Table 4: Tractor wheel slippage for cultivator

\begin{tabular}{ccccc}
\hline No & $\begin{array}{c}\text { Expected dist covered by } \\
\text { tractor wheel at no load }(\mathbf{c m})\end{array}$ & $\begin{array}{c}\text { Observed dist covered by } \\
\text { tractor wheel at load }(\mathbf{c m})\end{array}$ & $\begin{array}{c}\text { Wheel slip } \\
\mathbf{( \% )}\end{array}$ & $\begin{array}{c}\text { Average } \\
\mathbf{( \% )}\end{array}$ \\
\hline 1 & 3832 & 3295.5 & 14 & \\
2 & 3832 & 3372.1 & 12 & \\
3 & 3832 & 3295.2 & 14 & 14.4 \\
4 & 3832 & 3218.8 & 16 & \\
5 & 3832 & 3218.8 & 16 & \\
\hline
\end{tabular}

Table 5: Depth of operation with cultivator

\begin{tabular}{ccc}
\hline No & Depth of operation, $\mathbf{m m}$ & Average depth, $\mathbf{m m}$ \\
\hline 1 & 105 & \\
2 & 110 & 129.2 \\
3 & 124 & \\
4 & 145 & \\
5 & 162 & \\
\hline
\end{tabular}

Table 6: Soil inversion with cultivator

\begin{tabular}{cccccc}
\hline No & $\begin{array}{c}\text { Depth } \\
\text { (cm) }\end{array}$ & $\begin{array}{c}\text { No of weeds } \\
\text { before operation } \\
\text { per unit area }\end{array}$ & $\begin{array}{c}\text { No of weeds } \\
\text { after operation } \\
\text { per unit area }\end{array}$ & $\begin{array}{c}\text { Soil inversion } \\
\text { (\%) }\end{array}$ & $\begin{array}{c}\text { Average } \\
\text { (\%) }\end{array}$ \\
\hline 1 & 8.2 & 240 & 58 & 75.83 & \\
2 & 8.6 & 230 & 55 & 76.08 & 76.42 \\
3 & 10.5 & 218 & 52 & 76.14 & \\
4 & 12.2 & 242 & 56 & 76.85 & \\
5 & 12.5 & 215 & 49 & 77.20 & \\
\hline
\end{tabular}

Table 7: Field Capacity, Field Efficiency, Cost of Operation and Energy Requirement of cultivator

\begin{tabular}{lll}
\hline $\mathbf{1}$ & Actual operating time, min & 15.28 \\
$\mathbf{2}$ & Time lost owing to & \\
& I) Turning, sec. & 58 \\
& II) Adjustment, min & 1.12 \\
$\mathbf{3}$ & Actual area covered, ha & 0.21 \\
$\mathbf{4}$ & Effective working width, $\mathrm{m}$ & 2.10 \\
$\mathbf{5}$ & Traveling speed, km/h & 4.5 \\
$\mathbf{6}$ & Theoretical field capacity, ha/h & 0.945 \\
$\mathbf{7}$ & Effective field capacity, ha/h & 0.826 \\
$\mathbf{8}$ & Field efficiency, \% & 87.40 \\
$\mathbf{9}$ & Wheel slip of tractor \% & 14.4 \\
$\mathbf{1 0}$ & Fuel consumption, lit/ha & 4.08 \\
$\mathbf{1 1}$ & Weeding efficiency, \% & 76.42 \\
$\mathbf{1 2}$ & Cost of operation, Rs/ha & 434.43 \\
$\mathbf{1 3}$ & Energy requirement, MJ/ha & 51.04 \\
\hline
\end{tabular}

Table 8: Calibration of tractor drawn cultivator cum seed drill for exposed length and hopper capacity

\begin{tabular}{ccccccc}
\hline No & Crop & Exposed length $(\mathbf{m m})$ & \multicolumn{4}{c}{ Seed rate, $\mathbf{~ k g}$ /ha for different hopper capacity } \\
\hline \multirow{3}{*}{1} & \multirow{2}{*}{ paddy } & 11.2 & $\mathbf{4 9 . 0 7}$ & 55.41 & 64.94 & 67.99 \\
& 14.9 & 77.45 & 78.44 & $\mathbf{8 0 . 8 7}$ & 86.87 \\
& 18.6 & 102.50 & 107.74 & 117.54 & $\mathbf{1 2 4 . 0 9}$ \\
\hline
\end{tabular}

Table 9: Mechanical damage to seeds

\begin{tabular}{|c|c|c|c|c|c|c|c|}
\hline No & Crop & $\begin{array}{l}\text { Weight of } \\
\text { broken } \\
\text { seeds, (g) }\end{array}$ & $\begin{array}{c}\text { Total weight } \\
\text { of sample } \\
\text { (g) }\end{array}$ & $\begin{array}{c}\text { Broken } \\
\text { seeds (\%) }\end{array}$ & $\begin{array}{c}\text { Average } \\
\text { mechanical } \\
\text { damage } \% \\
\text { of seeds }\end{array}$ & $\sigma$ & cv \\
\hline 1 & Paddy & $\begin{array}{l}3.9 \\
4.0 \\
4.6\end{array}$ & $\begin{array}{c}226 \\
228.9 \\
236\end{array}$ & $\begin{array}{l}1.72 \\
1.74 \\
1.94\end{array}$ & 1.8 & 0.099 & 5.5 \\
\hline
\end{tabular}




\section{Moisture Content and Bulk Density of Soil}

Moisture content on dry basis of soil was measured by oven dry method five soil samples were taken randomly at $5.2,5.6,6,6.2$ and $6.8 \mathrm{~cm}$ depth from surface of soil using core sampler of $5.6 \mathrm{~cm}$ diameter and $8.6 \mathrm{~cm}$ height.

Moisture content at 5.2, 5.6, 6.0, 6.2 and $6.8 \mathrm{~cm}$ depth was found to be $14.43,14.72,14.01,15.45$, and 14.32 on dry basis respectively.Bulk density of soil was measured by core sampler. Bulk density of soil was found to be 1.20 , $1.19,1.20,1.20$, and $1.19 \mathrm{~g} / \mathrm{cm}^{3}$ at the respective depth (Table 10).

\section{Speed of Operation}

The speed of operation was calculated from the time required by the machine to travel the distance of $20 \mathrm{~m}$. the average speed of operation was found to be $3.09 \mathrm{~km} / \mathrm{h}$ (Table 11).

\section{Wheel Slippage}

The average wheel slippage for cultivator-cum-seed drill was found to be $8.8 \%$ (Table 12).

Table 10: Moisture Content and Bulk Density of Soil at respective depth

\begin{tabular}{|c|c|c|c|}
\hline No & Depth (cm) & Moisture content \% (db) & Bulk density $\left(\mathrm{g} / \mathrm{cm}^{3}\right)$ \\
\hline 1 & 5.2 & 14.43 & 1.20 \\
\hline 2 & 5.6 & 14.72 & 1.19 \\
\hline 3 & 6.0 & 14.01 & 1.20 \\
\hline 4 & 6.2 & 15.45 & 1.20 \\
\hline 5 & 6.8 & 14.32 & 1.19 \\
\hline
\end{tabular}

Table 11: Data pertaining to the field test of cultivator-cum-seed drill

\begin{tabular}{cccc}
\hline No & Distance $(\mathbf{m})$ & Time $(\mathbf{s})$ & Speed $(\mathbf{m} / \mathbf{s})$ \\
\hline $\mathbf{1}$ & 20 & 23.0 & 0.869 \\
$\mathbf{2}$ & 20 & 23.10 & 0.865 \\
$\mathbf{3}$ & 20 & 23.16 & 0.863 \\
$\mathbf{4}$ & 20 & 23.50 & 0.851 \\
$\mathbf{5}$ & 20 & 23.40 & 0.854 \\
\hline Average & $\mathbf{2 0}$ & $\mathbf{2 3 . 2 3}$ & $\mathbf{0 . 8 6 0}$ \\
\hline
\end{tabular}

Table 12: Tractor wheel slippage for cultivator-cum-seed drill

\begin{tabular}{ccccc}
\hline No & $\begin{array}{c}\text { Expected dist covered by } \\
\text { tractor wheel at no load } \mathbf{( c m )}\end{array}$ & $\begin{array}{c}\text { Observed dist covered by } \\
\text { tractor wheel at load } \mathbf{( c m )}\end{array}$ & $\begin{array}{c}\text { Wheel slip } \\
\mathbf{( \% )}\end{array}$ & $\begin{array}{c}\text { Average } \\
(\%)\end{array}$ \\
\hline $\mathbf{1}$ & 3832 & 3448.8 & 10 & \\
$\mathbf{2}$ & 3832 & 3487.12 & 9 & \\
$\mathbf{3}$ & 3832 & 3448.8 & 10 & 8.8 \\
$\mathbf{4}$ & 3832 & 3563.7 & 7 & \\
$\mathbf{5}$ & 3832 & 3525.4 & 8 & \\
\hline
\end{tabular}

\section{CONCLUSIONS}

The average mechanical damage to seed by cultivator-cum-seed drill was found to be $1.8 \%$ with standard deviation of 0.099 , with $\mathrm{CV}$ of $5.5 \%$ and that of conventional seed drill was $1.95,0.109$ and $5.6 \%$. The effective field capacity of the cultivator-cum seed drill was $0.537 \mathrm{ha} / \mathrm{h}$ with field efficiency $82.8 \%$ as compared to conventional seed drill which was $0.596 \mathrm{ha} / \mathrm{h}$ and 82.32 $\%$. The average depth of seed placement with cultivatorcum-seed drill was found to be $57.8 \mathrm{~mm}$ and that of conventional seed drill was $60.6 \mathrm{~mm}$. The cost of operation for cultivator-cum-seed drill was $591.08 \mathrm{Rs} / \mathrm{ha}$ and that for conventional seed drill was $535.016 \mathrm{Rs} / \mathrm{ha}$. The Energy requirement for cultivator-cum-seed drill was found to be $454.18 \mathrm{MJ} / \mathrm{ha}$ and that for conventional seed drill was found to be $416 \mathrm{MJ} / \mathrm{ha}$.

\section{Conflict of Internet}

Authors expressed no conflict of Interest

\section{REFERENCES}

Dixit, J., Gupta, R.S.R., Behl, V.P. and Singh, S. (2004). Notill seed-cum-fertilizer drill in wheat crop production after paddy harvesting. Agricultural Mechanization in Asia, Africa and Latin America 35(1):19-22.

Dubey, A.K. and Srivastava, N.S.L. (1985). Development of furrow openers for animal drawn seed-cum-fertilizer drill for black soils. Procedings of the ISAE SJC 1: 39-43.

Kaleemullah, S., Lakshmi Reddy, B and Singh, A.K. (1997). Development of a low-cost ferti-cum-seed drill. Agricultural Mechanization in Asia, Africa and Latin America 28(1): 26-28.

Shafaii, S. and Holmes, R.G. (1990). Air jet metering, a theoretical and experimental study. Transaction of the ASAE 33(5): 1432-1438.

Short Ted, H., Harber Samuel, G.(1970). The development of a planetary-vacuum seed metering device.Transactions of the ASAE 13(6): 803-805. 